\title{
Eukaryotic translation factor elF5A contributes to acetic acid tolerance in Saccharomyces cerevisiae via transcriptional factor Ume6p
}

\author{
Yanfei Cheng ${ }^{1 \dagger}$, Hui Zhu ${ }^{1,2 \dagger}$, Zhengda Du ${ }^{1,2}$, Xuena Guo $^{1}$, Chenyao Zhou ${ }^{1,2}$, Zhaoyue Wang ${ }^{1}$
} and Xiuping $\mathrm{He}^{1,2^{*}}$

\begin{abstract}
Background: Saccharomyces cerevisiae is well-known as an ideal model system for basic research and important industrial microorganism for biotechnological applications. Acetic acid is an important growth inhibitor that has deleterious effects on both the growth and fermentation performance of yeast cells. Comprehensive understanding of the mechanisms underlying S. cerevisiae adaptive response to acetic acid is always a focus and indispensable for development of robust industrial strains. elF5A is a specific translation factor that is especially required for the formation of peptide bond between certain residues including proline regarded as poor substrates for slow peptide bond formation. Decrease of elF5A activity resulted in temperature-sensitive phenotype of yeast, while up-regulation of elF5A protected transgenic Arabidopsis against high temperature, oxidative or osmotic stress. However, the exact roles and functional mechanisms of elF5A in stress response are as yet largely unknown.
\end{abstract}

Results: In this research, we compared cell growth between the elF5A overexpressing and the control S. cerevisiae strains under various stressed conditions. Improvement of acetic acid tolerance by enhanced elF5A activity was observed all in spot assay, growth profiles and survival assay. elF5A prompts the synthesis of Ume6p, a pleiotropic transcriptional factor containing polyproline motifs, mainly in a translational related way. As a consequence, BEM4, BUD21 and IME4, the direct targets of Ume6p, were up-regulated in elF5A overexpressing strain, especially under acetic acid stress. Overexpression of UME6 results in similar profiles of cell growth and target genes transcription to elF5A overexpression, confirming the role of Ume6p and its association between eIF5A and acetic acid tolerance.

Conclusion: Translation factor elF5A protects yeast cells against acetic acid challenge by the elF5A-Ume6p-Bud21p/ Ime4p/Bem4p axles, which provides new insights into the molecular mechanisms underlying the adaptive response and tolerance to acetic acid in S. cerevisiae and novel targets for construction of robust industrial strains.

Keywords: Saccharomyces cerevisiae, Translation factor elF5A, Transcription factor Ume6p, Acetic acid tolerance

*Correspondence: hexp@im.ac.cn

†Yanfei Cheng and Hui Zhu contributed equally to this manuscript

${ }^{1}$ CAS Key Laboratory of Microbial Physiological and Metabolic

Engineering, State Key Laboratory of Mycology, Institute of Microbiology, Chinese Academy of Sciences, Beijing 100101, China

Full list of author information is available at the end of the article

\section{Background}

eIF5A, originally discovered and identified as an eukaryotic translation initiation factor (eIF), is a small (16$18 \mathrm{kDa}$ ) cellular protein containing the unique amino acid hypusine [ $\mathrm{N}^{\epsilon}$-(4-amino-2-hydroxybutyl)lysine], which is formed from a specific lysine residue in eIF5A 
via posttranslational modification [1-6]. The hypusine modification of eIF5A involves two enzymatic reactions, in which deoxyhypusine synthase (DHS) catalyzes the transfer of a $n$-butylamine moiety from the polyamine spermidine to one specific lysine residue of the eIF5A precursor to form deoxyhypusine intermediate, then deoxyhypusine hydroxylase $(\mathrm{DOHH})$ catalyzes the hydroxylation of deoxyhypusine to form hypusinecontaining, biologically active eIF5A $[4,6]$. Both eIF5A precursor and its hypusine modification are highly conserved and essential in all archaea and eukaryotes, suggesting the importance of active eIF5A in these organisms [5-13]. eIF5A was initially characterized to function in initiation of protein synthesis for its ability to stimulate the synthesis of methionyl-puromycin, a model reaction indicating the synthesis of the first peptide bond [1-3]. Such function was also observed for eIF5A in Saccharomyces cerevisiae [14]. However, several researches confirmed the role for eIF5A in translation elongation rather than translation initiation, as its depletion resulted in the increased polysomes in ribosome run-off experiments, yielding polysome profiles similar to those of elongation factor mutants [15-17], and functional interactions with structural components of the $80 \mathrm{~S}$ ribosome and elongation factor eEF2 were observed for eIF5A [15, 18]. Only about $30 \%$ decrease in the overall protein synthesis was observed in eIF5A rapid-deletion yeast cells [14, 19], indicating that eIF5A appears to facilitate translation of some specific mRNAs rather than involvement in general protein synthesis. The specific requirement for eIF5A in translation of sequence-specific proteins that contain at least three consecutive proline residues was revealed by in vivo assays in yeast and in vitro reconstituted translation assays, in which eIF5A binds near the $\mathrm{E}$ and $\mathrm{P}$ sites of the $80 \mathrm{~S}$ ribosome with its hypusine residue pointing to the peptidyl transferase center to prevent ribosome stalling on consecutive proline codons and promote the translation through polyproline [20]. Proline-rich proteins occur widely in eukaryotic organisms, and the number and frequency of polyproline motifs increase with biological complexity of organisms, which indicate their functional significance [21-23]. However, the precise relations between the activity of eIF5A and the specialized target proteins, and their physiological roles remain elusive and need to be further elucidated.

S. cerevisiae is an ideal model system for eukaryote, and moreover is an important organism for biotechnological applications. Yeast cells might suffer from various environmental stresses during the process of fermentation, such as high temperature, oxidative stress, osmotic stress and inhibitors, which have deleterious effects on both the cell growth and fermentation performance [24-26]. Acetic acid is not only one of the crucial inhibitors in lignocellulosic hydrolysates, an important non-feedstock substrate, but a byproduct of $S$. cerevisiae fermentation as well, and also an effective preservative [25, 27-31]. Acidification of intracellular environment and accumulation of acetate anion are the main causative factors for the cytotoxicity of acetic acid, which result in arrest of cell growth and metabolic activity [28, 32-34]. Comprehensive understanding of the mechanisms underlying yeast response to acetic acid is always a focus of research and indispensable for development of robust yeast strains for industrial applications.

In $S$. cerevisiae, eIF5A is encoded by two homologous genes, HYP2 and ANB1. HYP2 is essential and mainly expresses under the aerobic condition, whereas the nonessential ANB1 expresses only under the anaerobic condition $[11,35]$. The $S$. cerevisiae eIF5A precursor is modified at the $\varepsilon$-amino group of Lys51 to form hypusine, which is catalyzed successively by DHS and DOHH encoded by DYS1 and LIA1, respectively [10, 12 , 36]. Mutation at Lys51 of eIF5A leads to lethal effect on yeast cells, while some other mutations in eIF5A result in temperature-sensitive phenotype [17, 37, 38]. In our previous comparative transcriptome analyses, downregulation of DYS1 and LIA1 was observed under heat stress for temperature-sensitive yeast strain (unpublished data). According to the above information, we hypothesized that eIF5A might involve in yeast response to environmental stresses. In this study, the role and functional mechanism of eIF5A in S. cerevisiae response to acetic acid were investigated.

\section{Results}

\section{Overexpression of elF5A enhances acetic acid tolerance of yeast cells}

Cell growth of yeast strains overexpressing HYP2, DYS1 or LIA1 on synthetic complete medium SC-Ura under various stress conditions were compared with the control strain by spot assay first. No significant difference in growth was observed among these yeast strains under heat, furfural or ethanol stress (Fig. 1), while the eIF5A overexpressing strain YS58-HYP2 exhibited resistance to acetic acid compared with the control strain YS58-V (Fig. 1a).

To validate the results of spot assay, the transcription levels of related genes in various yeast strains and cell growth in liquid SD-Ura medium with different concentrations of acetic acid were determined (Fig. 2). The enhanced transcription of HYP2, DYS1 or LIA1 in strain YS58-HYP2, YS58-DYS1 or YS58-LIA1 was confirmed, respectively, by qRT-PCR (Fig. 2a). There was no obvious growth difference among these yeast strains under non-stressed condition (Fig. 2b). Cell growth of 

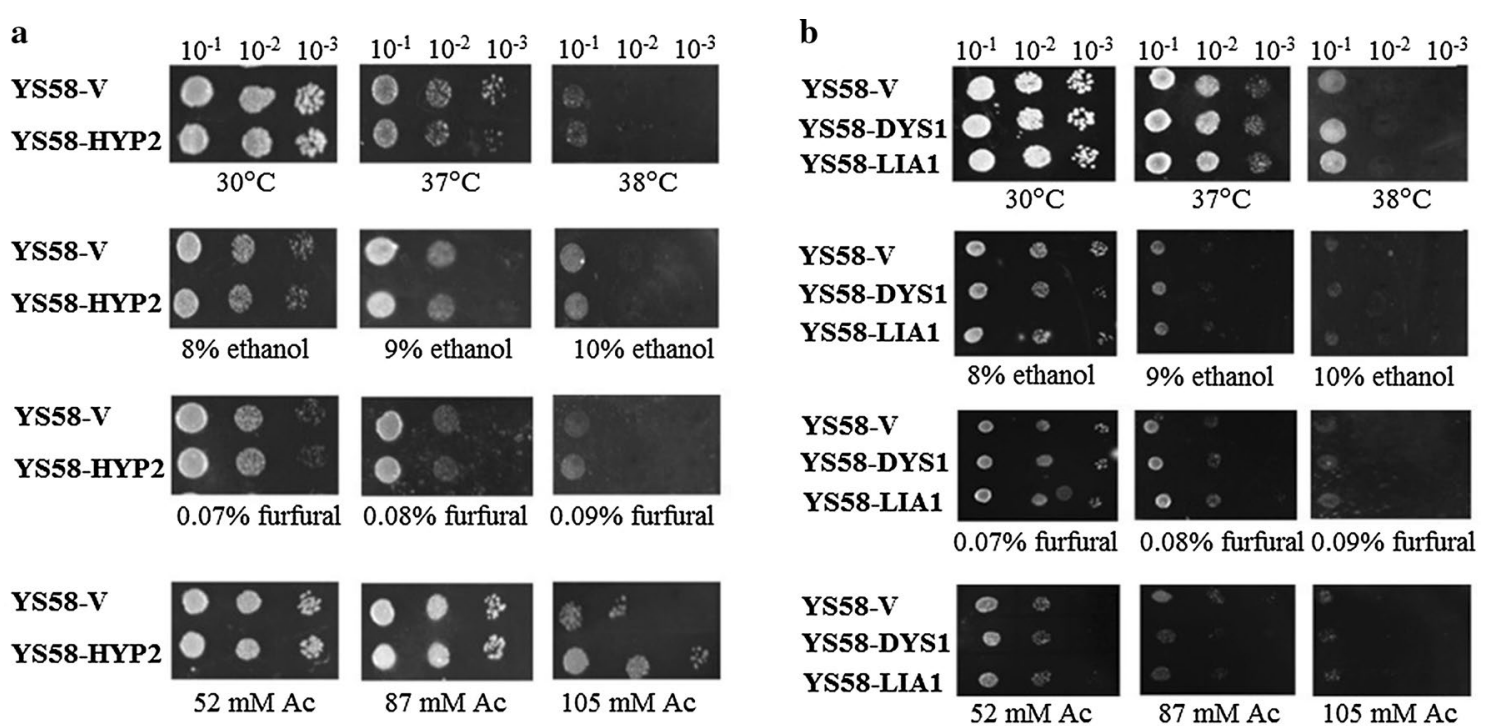

Fig. 1 Comparison of cell growth among different yeast strains under various stressed conditions by spot dilution assay. a Comparison between HYP2-overexpressing strain and the control strain. $\mathbf{b}$ Comparison between yeast strains with enhanced hypusine modification and the control strain. Yeast cells were cultured on SC-Ura medium with or without inhibitors at $30^{\circ} \mathrm{C}$ or other temperature

all strains was impaired under acetic acids stress, but less influence on eIF5A-overexpressing strain YS58HYP2 was observed, which displayed much shorter lag time and higher growth efficiency than the control strain YS58-V in the presence of $87 \mathrm{mM}$ acetic acid (Fig. 2c). When the concentration of acetic acid was increased to $105 \mathrm{mM}$, growth of the control strain YS58-V was suppressed almost completely, whereas cells of YS58-HYP2 could still grow with around 50\% growth rate of that in the absence of acetic acid after a longer lag time of about $30 \mathrm{~h}$ (Fig. 2d). Enhancement of DYS1 expression only improved the cell growth slightly under acetic acid stressed conditions, while overexpression of LIA1 displayed similar growth profiles to the control strain under the various conditions (Fig. 2c and d). In the presence of $87 \mathrm{mM}$ acetic acid, the transcription level of HYP2 in YS58-HYP2 were 1.8 and 6.1 times of those of the control strain, respectively, in early-exponential growth phase and mid-exponential growth phase (Fig. 2a), indicating a correlation between acetic acid tolerance and higher transcription level of eIF5A. In further survival assay, higher survival rate was obtained for strain YS58-HYP2 in the presence of $210 \mathrm{mM}$ acetic acid (Fig. 2e). In the preliminary fermentation, higher glucose utilization in YS58-HYP2 than in YS58-V was observed in the presence of $87 \mathrm{mM}$ acetic acid (Additional file 1: Figure S1). These results suggest that eIF5A protects yeast cells against acetic acid damage in S. cerevisiae.

\section{The possible targets of elF $5 \mathrm{~A}$ mediating acetic acid} tolerance

It has been reported that eIF5A is required for synthesis of proteins containing polyproline motifs through stimulating peptide bond formation between prolines in translation elongation step [20]. Thus, we proposed that enhancement of eIF5A might promote the translation of proline repeat-rich proteins which involve in response to acetic acid stress. To test this hypothesis, bioinformatics retrieval and analysis were conducted firstly. Five hundred and fifty eight yeast proteins with polyproline stretches (at least triple proline residues, PPP or 3P) were found in Saccharomyces Genome Database (SGD, http:// www.yeastgenome.org/download-data/sequence). In the functional screening of EUROSCARF nonessential genes deletion collection, there were 216 genes whose deletion caused the sensitive phenotype to $0.5 \%$ acetic acid at $\mathrm{pH}$ 4.2 [39]. About 650 genes whose deletion caused the sensitive phenotype to 70,90 and $110 \mathrm{mM}$ acetic acid at $\mathrm{pH}$ 4.5 were identified in the screening of the same mutant collection [29]. In another screening of the same mutant collection for genes involved in the positive and negative regulation of acetic acid-induced programmed cell death (PCD) by analysis the amount of culturable cells in the presence of $400 \mathrm{mM}$ acetic acid at $\mathrm{pH} 3.0$, there were 409 genes whose deletion caused the sensitive phenotype to acetic acid [40]. After consistency analysis of the three datasets to exclude the repeats, a total of 1031 genes were obtained and regarded as the potential genes involved in tolerance to acetic acid. Among the 558 


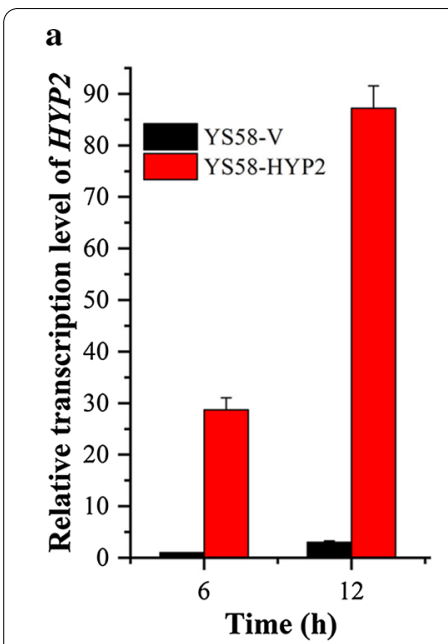

b
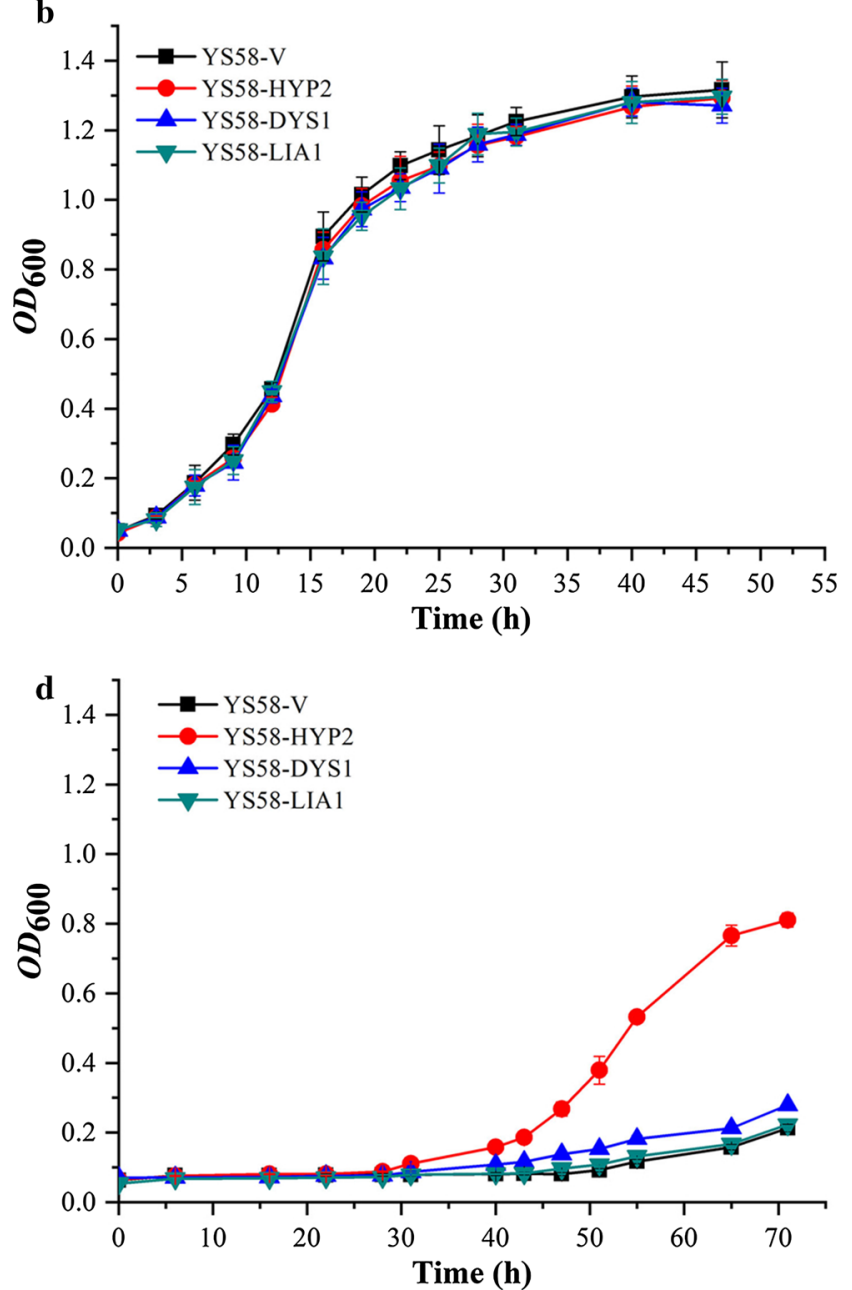
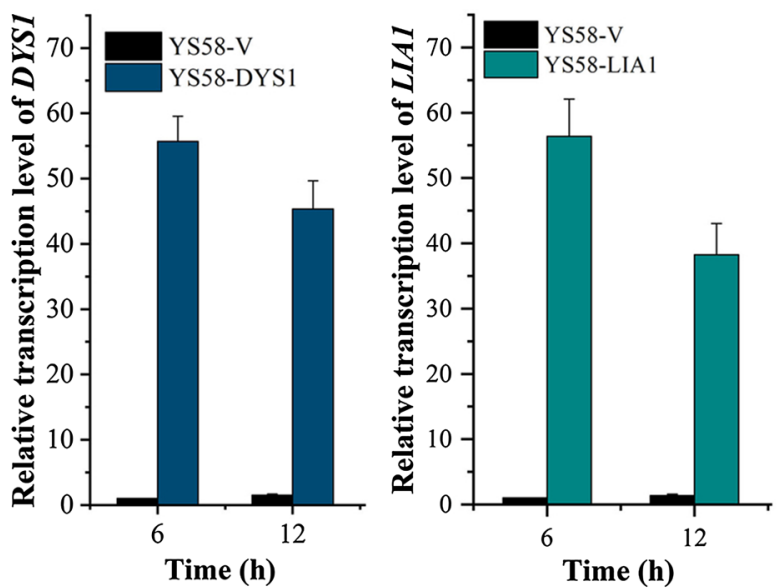

c
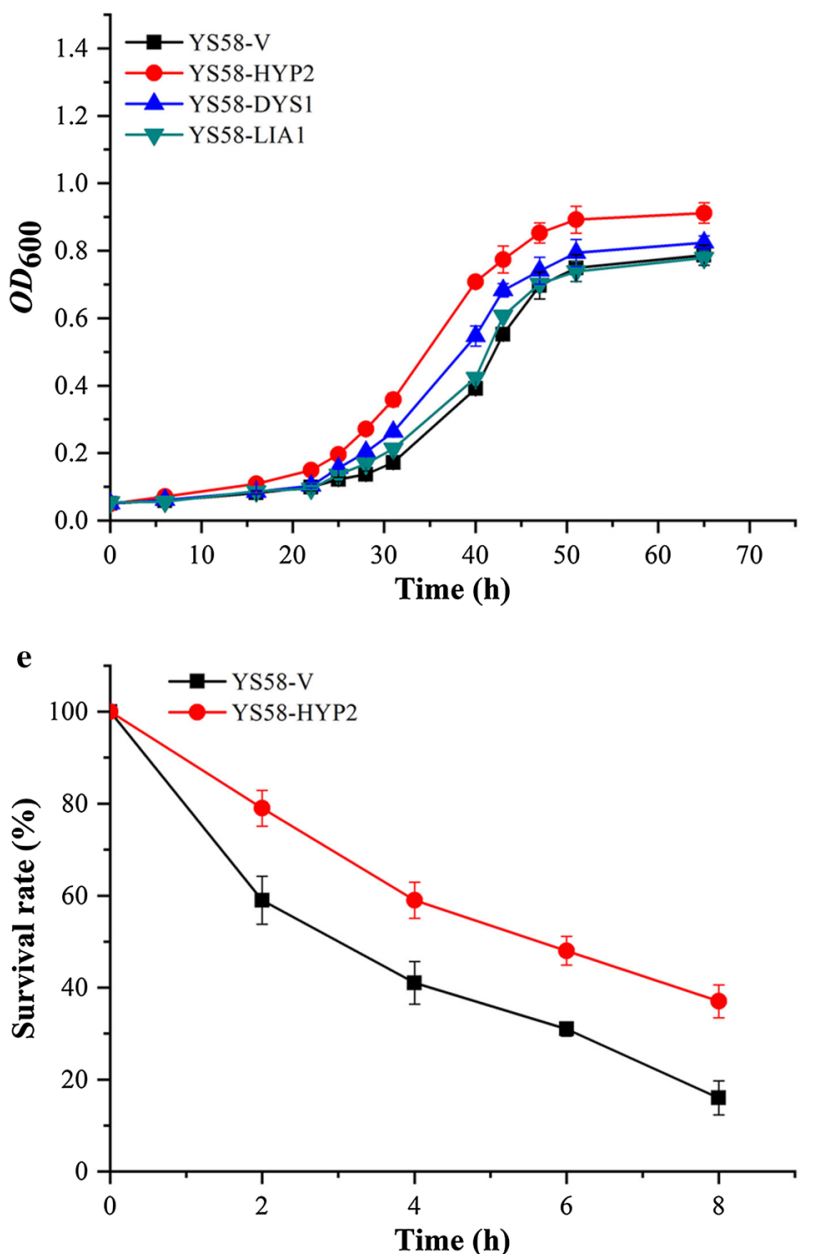

Fig. 2 Expression levels of elF5A relative genes and growth curves of different yeast strains. a Relative transcription levels of HYP2, DYS1 and LIA1 under conditions with or without acetic acid stress. The relative transcription levels of HYP2, DYS1 and LIA1 in the control strain YS58-V under non-stressed condition were defined as a value of 1. b Cell growth without acetic acid. c Cell growth in the presence of $87 \mathrm{mM}$ acetic acid ( $\mathrm{pH} 4.2$ ). d Cell growth in the presence of $105 \mathrm{mM}$ acetic acid (pH 4.2). e Survival assay of different yeast strains after $210 \mathrm{mM}$ acetic acid treatment (pH 4.2). Data are presented as the means of the results of three independent experiments. Error bars represent standard deviations 
polyproline proteins coding genes and 1031 genes possibly related to acetic acid tolerance, 85 genes common to the two datasets were identified and clustered according to the Gene ontology (GO) annotations available on SGD based on specific biological process and molecular function of the genes, which are mainly involved in chromatin remodeling, transcriptional regulation, RNA processing, protein modification, intracellular trafficking and sorting or degradation, signal transduction, cytoskeleton organization and morphogenesis, cell wall function, metabolism and mitochondrial function (Fig. 3) (Additional file 1: Table S1). Among the 85 common genes, there are 17 genes encoding proteins with multiple PPP motifs $(\geq 2 \times 3 \mathrm{P})$ or longer consecutive proline residues ( $\geq$ PPPP), which might require much higher eIF5A activity for peptide bond formation between consecutive proline residues. Hence, they were chosen for further investigation for their more dependence on eIF5A activity.

\section{Influence of elF5A levels on the abundance of polyproline proteins related probably to acetic acid tolerance}

GFP-tagged strategy was exploited to compare abundance of the polyproline proteins in yeast cells (Fig. 4a). A series of recombinant yeast strains were constructed, in which the native locus of the polyproline protein encoding gene on chromosome was replaced by a $g f p$-fused form to produce GFP-tagged target protein, respectively. Plasmid pYEAH was introduced into the above recombinant strains to obtain strains YS58-XG-HYP2, while the corresponding references YS58-XG-V with empty vector pYEA were also obtained. The enhanced transcription of HYP2 similar to YS58-HYP2 was confirmed by qRTPCR. The RFU of GFP in constructed strains was assayed and compared under $87 \mathrm{mM}$ acetic acid stressed or non-stressed condition for $4 \mathrm{~h}$ and $8 \mathrm{~h}$, respectively, to characterize the levels of target proteins (Fig. 4b, c). The changing trend of abundance of each protein at the two time points was almost accordant. For ease of comparison, results of cultivation for $4 \mathrm{~h}$ in the absence or presence of $87 \mathrm{mM}$ acetic acid were presented. Among them, the abundance of Ume6p increased largely in HYP2-overexpressing strain under both conditions, which were 1.6fold and 2.7-fold under non-stressed condition and acetic acid stress for $4 \mathrm{~h}$ compared with the respective control strain (Fig. 4b, c). Moreover, induction of Ume6p by acetic acid was observed, which confirmed its roles in S. cerevisiae response to acetic acid.

To further validate the role of eIF5A in synthesis of Ume6p, both the transcription level of UME6 and the protein level of Ume6p were analyzed (Fig. 4d). Under non-stressed condition, there was no obvious difference in mRNA level of UME6, but $67 \%$ increase in Ume6p abundance was observed in eIF5A overexpressing strain compared to the control strain, which indicated that the enhanced eIF5A activity supported $67 \%$ increase in translation efficiency of UME6 mRNA. Increases in both mRNA level and Ume6p abundance occurred in strains YS58-UME6G-V and YS58-UME6G-HYP2 in the presence of $87 \mathrm{mM}$ acetic acid, which were 1.6 and 2.4 times in the control strain, 2.7 and 4.1 times in eIF5A overexpressing strain of those under non-stressed condition. The translation efficiency of UME6 mRNA was 69\% higher in YS58-UME6G-HYP2 than YS58-UME6G-V in
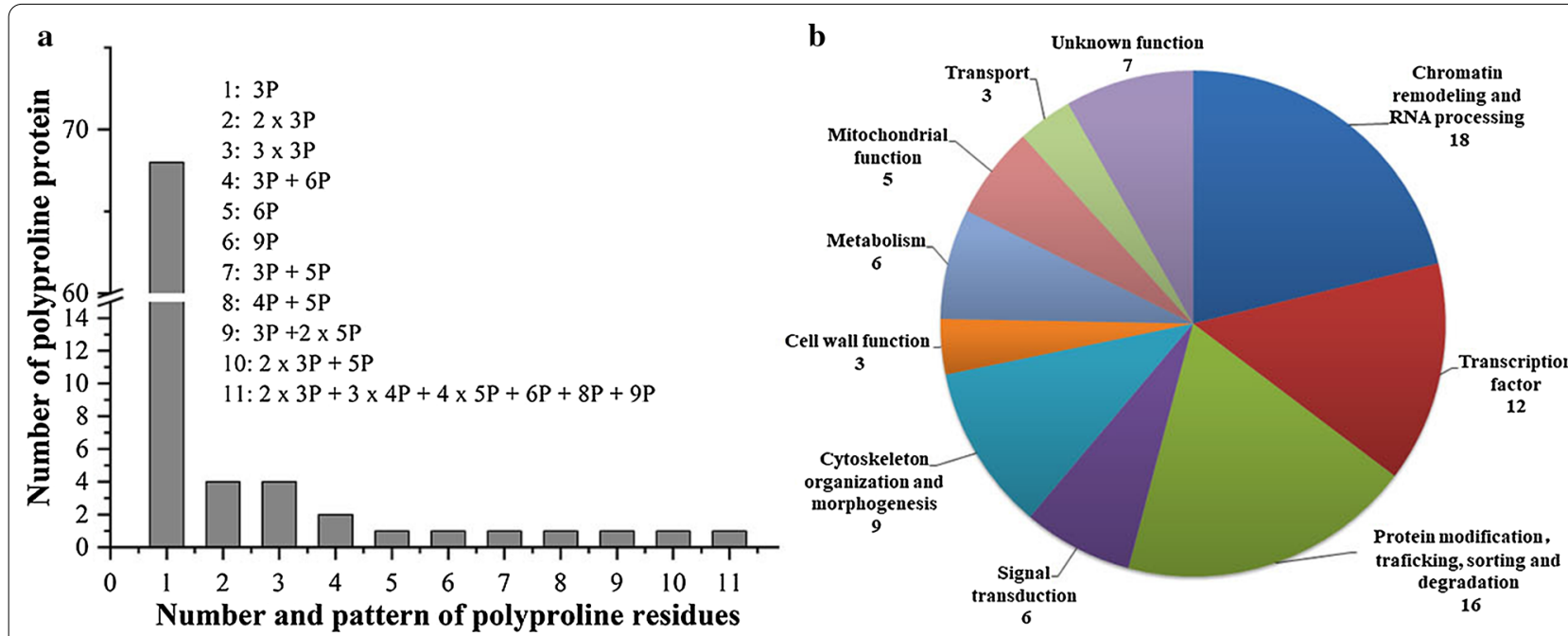

Fig. 3 Patterns of polyproline residues (PPP) and the functional ontology diagram of S. cerevisiae polyproline proteins involved possibly in tolerance to acetic acid. a Numbers and patterns of polyproline residues. $\mathbf{b}$ Functional ontology 


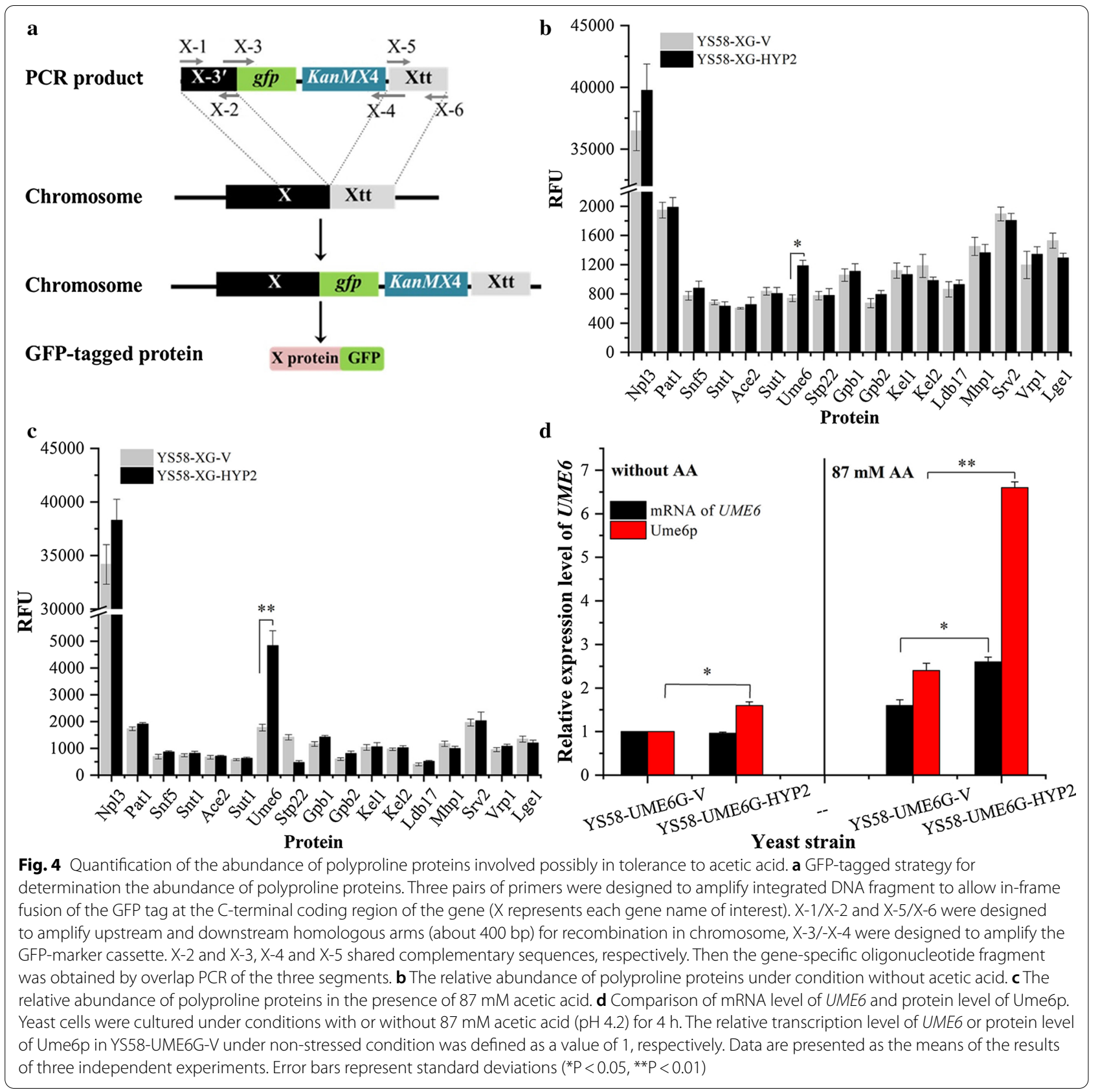

the presence of $87 \mathrm{mM}$ acetic acid. These results confirm that the elevated eIF5A promotes the synthesis of Ume6p in mainly a translational related way.

\section{Transcriptional activation of key targets of Ume6p}

Ume6p is regarded as a pleiotropic transcriptional factor involved in response to nutritional changes or stresses, meiosis and hyphal development [29, 41-44]. To further verify the role of Ume6p in acetic acid response, the target genes regulated potentially by Ume6p were predicted by using the YEASTRACT database (http://www.yeast ract.com). A total of 1481 potential target genes were searched, in which 170 genes were regarded as the direct targets for the consensus sequence in promoters. One hundred and seventy-six Ume6p target genes whose deletion led to sensitive phenotype to acetic acid were found by consistency comparison between target genes of Ume6p and genes potentially related to acetic acid tolerance, among which 24 genes were the direct targets of Ume6p (Fig. 5a). Divergences in transcriptional profiles of 


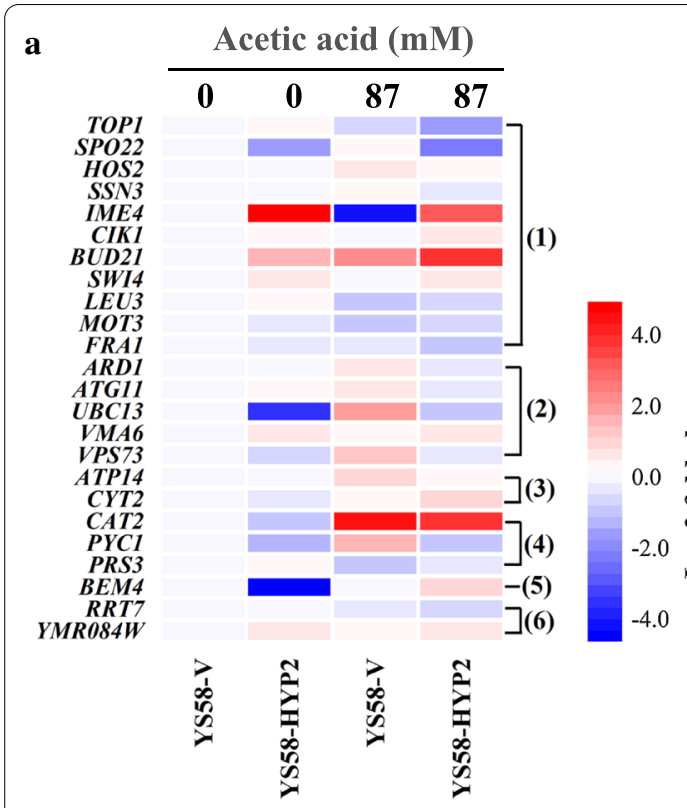

d

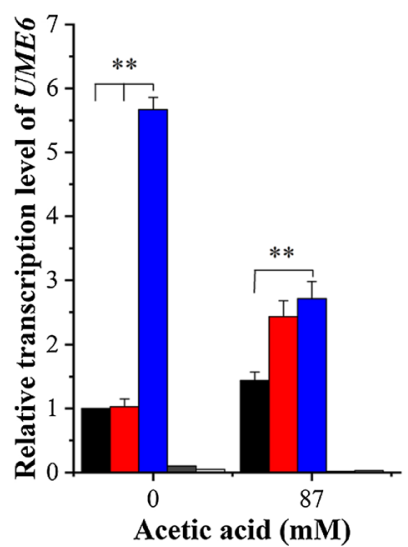

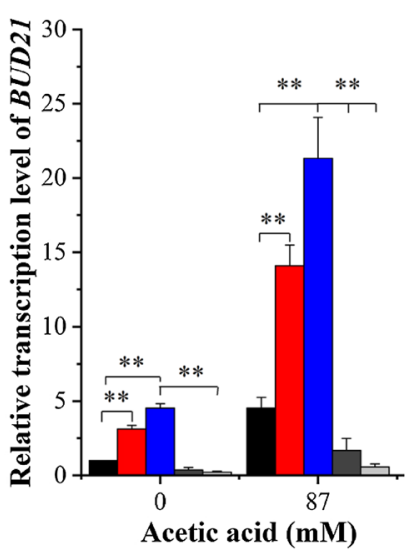

Acetic acid (mM)

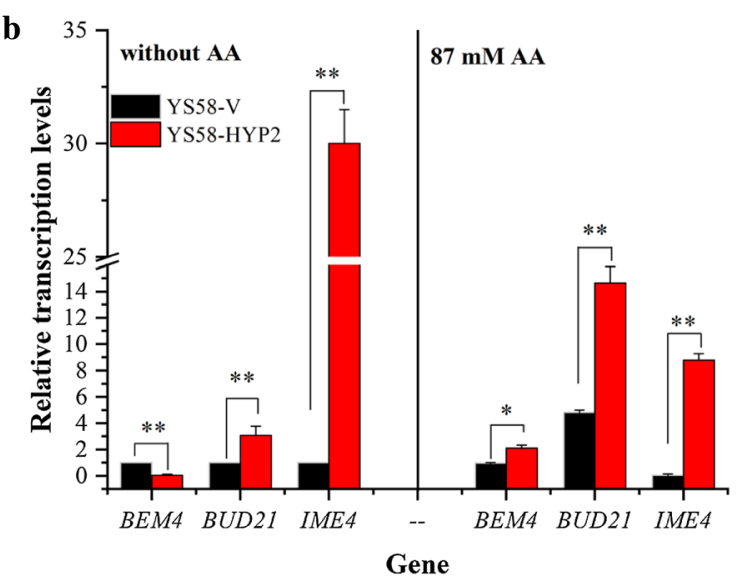

Acetic acid (mM)

c

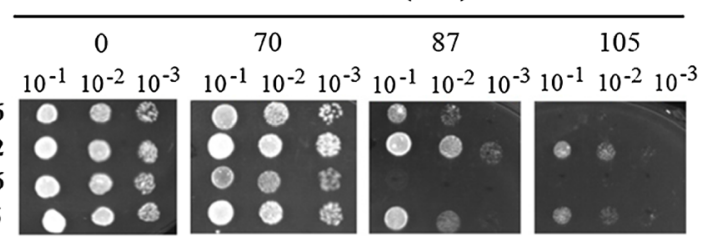

Fig. 5 Ume6p mediates the effect of HYP2 overexpression on yeast cells response to acetic acid. a Direct targets of Ume6p involved in acetic acid response. The log2 values of relative transcription levels were compared. (1) Genes involved in chromatin remodeling, transcription and RNA processing. (2) Genes involved in protein modification, trafficking and sorting. (3) Genes involved in mitochondrial function. (4) Genes involved in carbohydrate metabolism. (5) Gene involved in remodeling and maintaining cell wall architecture. (6) Unknown function. b Transcription levels of Ume6p direct targets. c Effect of Ume6p activity on cell growth upon acetic acid stress. $\mathbf{d}$ Effect of Ume6p activity on transcription of BEM4, BUD21 and IME4. Yeast cells were cultured under conditions with or without $87 \mathrm{mM}$ acetic acid ( $\mathrm{pH} 4.2)$ for $4 \mathrm{~h}$. The relative transcription of target gene in YS58-V under non-stressed condition was defined as a value of 1, respectively. Data are presented as the means of the results of three independent experiments. Error bars represent standard deviations $\left({ }^{*} P<0.05\right.$, $\left.{ }^{* *} \mathrm{P}<0.01\right)$

the direct target genes of Ume6p were observed between the eIF5A overexpressing strain and the control strain under both conditions. The transcription of BUD21, $C A T 2, P Y C 1, V P S 73$ and $U B C 13$ was enhanced largely, but the transcription of IME4 was repressed severely by acetic acid in the control strain, while the mRNA levels of other genes displayed no obvious changes between non-stressed and stressed conditions. In eIF5A overexpressing yeast cells, genes $B U D 21$ and IME4 were up-regulated, while transcription of $P Y C 1$ and $S P O 22$ was repressed compared to the control cells under both non-stressed and stressed conditions. Transcription of $B E M 4$ and $U B C 13$ were repressed in eIF5A overexpressing yeast cells cultured under non-stressed condition, but they were de-repressed in the presence of acetic acid. The other genes showed no obvious change in mRNA levels 
across different strains and culture conditions. Under acetic acid stressed condition, eIF5A overexpressing strain produced much higher level of mRNA of BEM4, BUD21 and IME4 than the control strain (Fig. 5b), which suggested that Bem4p, Bud21p and Ime4p might mediate the acetic acid tolerance endowed by eIF5A overexpression. Among them, BUD21 is the sole gene up-regulated by both acetic acid (4.8-fold) and eIF5A (3.1-fold), suggesting its importance in yeast response to acetic acid challenge.

Furthermore, influence of UME6 deletion or overexpression on yeast cell growth and transcription of key target genes were investigated. Susceptible phenotype to acetic acid was observed in strains YS58-ume6 and YS58-HYP2-ume6, while protective effect of enhanced Ume6p on yeast cells against acetic acid stress occurred (Fig. 5c), suggesting the significance of Ume6p. However, strain YS58-ume6 was more sensitive to acetic acid than strain YS58-HYP2-ume6, while strain YS58-HYP2 was more resistant to acetic acid than strain YS58-UME6, indicating there may be other eIF5A-dependent proteins involving in protection yeast cells from acetic acid stress. Reduction of BUD21 and IME4 mRNA levels was observed in ume6 $\triangle$ mutants YS58-ume6 and YS58HYP2-ume6, while mRNA levels of BUD21 and IME4 were increased by overexpression of $U M E 6$, no matter acetic acid stress or not (Fig. 5d) (Additional file 1: Figure S2). Activation of BEM4 occurred in ume $6 \triangle$ mutants, while $B E M 4$ was repressed by enhanced expression of UME6 under non-stressed condition and de-repressed under acetic acid stressed condition (Fig. 5d). Similar growth profiles and transcription patterns of Ume6p target genes in HYP2 overexpression and UME6 overexpression genetic backgrounds suggest that Ume6p plays key function in tolerance to acetic acid endowed by eIF5A.

\section{Discussion}

As an important factor involved in translation, eIF5A is essential for eukaryotic vitality. However, it is necessary only for synthesis of some specific proteins containing polyproline motifs (at least three consecutive proline residues, PPP) [20], or other poor substrates for formation of peptide bond, such as glycine, arginine, lysine, aspartic acid or glutamic acid [45-47]. The proteins under eIF5A control relate to various biological processes, including cell wall integrity and cytoskeleton organization, cycle and cell differentiation, mRNA synthesis and turnover, and so on $[23,45,48]$. However, the key factors mediating the association between eIF5A activity and specific functional groups are poorly understood. Temperature-sensitive phenotype was observed in eIF5A and its hypusine modification mutants [17, 37, 38, 49]. Up-regulation of eIF5A in Rosa chinensis under high temperature, oxidative or osmotic stress condition, and its protective effect on transgenic Arabidopsis against above stresses were observed [50]. These results suggest that eIF5A might involve in response to environmental stresses. In this study, the effect of enhanced eIF5A activity on the tolerance of yeast cells to various stresses was investigated. Cell growth profiles under different stressed conditions indicate that the enhancement of eIF5A protects yeast cells from acetic acid damage rather than other stresses, which is a novel role for eIF5A involved in stress response.

Acetic acid is one of the common inhibitors that yeast cells suffer during growth and fermentation processes. Programmed cell death can be induced by lethal concentrations of acetic acid by apoptosis or necrosis, while sublethal concentrations of acetic acid may cause lower cell growth after extended period of growth arrest [34]. Hence, prolongation of lag phase is a typical characteristic of acetic acid damage, while short-term adaptation in robust strains facilitates the fermentation performance of $S$. cerevisiae in the presence of acetic acid [31, 51, 52]. Much shorter lag period and higher growth efficiency was observed for HYP2-overexpressing strain YS58HYP2 than the control strain YS58-V in the presence of $87 \mathrm{mM}$ acetic acid, and growth of the control strain YS58-V was suppressed almost completely whereas cells of YS58-HYP2 could still grow after an extended lag period of about $30 \mathrm{~h}$ when the concentration of acetic acid was increased to $105 \mathrm{mM}$ (Fig. 3). The robustness of HYP2-overexpressing strain YS58-HYP2 under acetic acid stress confirmed the involvement of eIF5A in tolerance to acetic acid.

Proline residues are regarded as the poorest substrates for peptide bond formation for the unique geometric conformations, and translation of polyproline peptides might require much more eIF5A activity [20]. So, we proposed that the improvement of yeast tolerance to acetic acid by overexpression of HYP 2 might be mediated by some specific polyproline proteins. Shared analysis between polyproline proteins-encoding genes and candidate genes leading to sensitivity to acetic acid after deletion $[29,39,40]$ was conducted to identify a total of 85 common genes, among which the abundance of protein encoded by UME6 was increased significantly by overexpression of $H Y P 2$, suggesting that Ume6p might play a positive role in associating eIF5A activity and tolerant phenotype to acetic acid.

Ume6p (Unscheduled Meiotic Expression 6), initially identified as a repressor of meiosis-specific genes, is a global pleiotropic transcriptional factor, which has been found to play positive or negative roles in diverse biological processes, including carbon and nitrogen metabolism, DNA repair, meiosis and hyphal development, cell 
wall biogenesis and maintenance [41-44]. More than one thousand genes in S. cerevisiae genome are putative under the control of Ume6p, in which genes with upstream repressor site 1 (URS1) within promoters are regarded as the direct targets $[42,44,53,54]$. The regulatory roles of Ume6p during meiosis have been well studied, in which Ume6p interacts with URS1 motif and recruits the conserved histone deacetylase Rpd3 through the co-repressor Sin 3 and the chromatin-remodeling factor Isw2 to repress the target genes [41, 54]. In response to environmental changes, acetylation of Ume6p occurs, leading to its release from promoters and the subsequent degradation, allowing the induction of target gene transcription [54-56]. However, the transcription levels of some genes with URS1 motif did not change in ume6 $\Delta$ mutant [54], while some genes without the URS1 were bound and positively regulated by Ume6p [57], suggesting that the roles and regulatory mechanisms of Ume6 are much more complex than those in meiosis. The involvement of Ume6p in acetic acid response was first reported by genome-wide screening $S$. cerevisiae haploid mutants sensitive to acetic acid [29], but the roles and the underlying mechanisms of this polyphonic transcription factor in acetic acid response are yet to be explored and confirmed. Among 24 of Ume6p direct target genes leading to sensitivity to acetic acid after deletion, transcription of BEM4, BUD21 and IME4 was up-regulated largely by eIF5A overexpression under acetic acid stress, indicating that Bem4p, Bud21p and Ime4p might involve in acetic acid tolerance caused by eIF5A overexpression. Further analyses of UME6 deletion or overexpression confirmed the dependency of BUD21, IME4 and BEM4 transcription on Ume6p. These results suggest that eIF5A-Ume6p switch regulates $S$. cerevisiae tolerance to acetic acid probably by promoting ribosome biogenesis through Bud21p, a component of the small ribosomal subunit processosome [58], remodeling and maintaining cell wall architecture through Bem $4 p$ activation of the cell wall integrity pathway [59], and Ime4p-mediated epitranscriptional regulation by $\mathrm{m}^{6} \mathrm{~A}$ methylation of target mRNAs [60-62]. In particular, BUD21 is the sole gene up-regulated by both acetic acid (4.8-fold) and eIF5A (3.1-fold), suggesting its importance in protecting yeast cells from acetic acid challenge. The further investigation needs to be conducted to reveal the exact roles of Bem4p, Bud21p and Ime4p in S. cerevisiae response to acetic acid, especially in that associated with eIF5A.

\section{Conclusions}

In conclusion, the involvement of translation factor eIF5A in S. cerevisiae response to acetic acid stress is confirmed in this study. eIF5A prompts the synthesis of a pleiotropic transcription factor Ume6p, which facilitates the transcription of multiple target genes to maintain normal biological processes, including ribosome biogenesis, cell wall biogenesis, epitranscriptional regulation and so on. Results in this study provide new insights into the molecular mechanisms underlying the adaptive response to acetic acid in $S$. cerevisiae by implicating eIF5A-Ume6p-Bud21p/Ime4p/Bem4p axles as signaling modules to endow yeast cells tolerance to acetic acid. Nevertheless, it is noteworthy that eIF5A-dependent proteins include more than those investigated in this study, the roles of other proteins under the control of eIF5A in acetic acid response need to be further investigated. On the other hand, only genes reported currently as both the direct target of Ume6p for the existence of the consensus sequence and involving in response to acetic acid were investigated in this study. Whether other target genes of Ume6p function in tolerance to acetic acid endowed by eIF5A requires further investigation. Moreover, in view of the significance of $\mathrm{m}^{6} \mathrm{~A}$ methylation modification of mRNA in regulation of gene expression, the physiological association of $\mathrm{m}^{6} \mathrm{~A}$ methylation with adaptive response and tolerance to acetic acid will be also explored in the future works.

\section{Materials and methods}

\section{Strains and growth conditions}

Escherichia coli DH5a (supE44 AlacU169 ( $\phi 80 l a c Z \Delta M 15)$ hsdR17 recA1 endA1 gyrA96 thi-1 relA1) was used as a general host for plasmid propagation. $S$. cerevisiae YS58 (MAT $\alpha$ flo1 leu2-3,112 his4-519 trp1719 ura3-52) [63] was used as the host for overexpression or deletion of target genes and construction of yeast strains with GFP-tagged proteins. The derivative yeast strains are listed in Additional file 1: Table S2. E. coli cells were grown at $37{ }^{\circ} \mathrm{C}$ in Luria-Bertani (LB) medium [64]. When necessary, $100 \mu \mathrm{g} / \mathrm{mL}$ of ampicillin was used in LB medium. Yeast cells were grown generally at $30{ }^{\circ} \mathrm{C}$ in YPD medium [65]. To screen or analyze yeast transformants, YPD medium containing $500 \mu \mathrm{g} / \mathrm{mL}$ of G418, synthetic complete medium (SC) containing $10 \mathrm{~g} / \mathrm{L}$ glucose, $6.7 \mathrm{~g} / \mathrm{L}$ yeast nitrogen base without amino acids, $40 \mathrm{mg} / \mathrm{L}$ histidine, $40 \mathrm{mg} / \mathrm{L}$ tryptophan, $40 \mathrm{mg} / \mathrm{L}$ leucine and $30 \mathrm{mg} / \mathrm{L}$ uracil or SC medium without uracil (SC-Ura) were also used. For preliminary fermentation, yeast cells were cultivated at $30{ }^{\circ} \mathrm{C}$ and $60 \mathrm{rpm}$ in synthetic complete fermentation medium (SCFM) containing $100 \mathrm{~g} / \mathrm{L}$ glucose, $6.7 \mathrm{~g} / \mathrm{L}$ yeast nitrogen base without amino acids, $5 \mathrm{~g} / \mathrm{L}$ urea, $40 \mathrm{mg} / \mathrm{L}$ histidine, $40 \mathrm{mg} / \mathrm{L}$ tryptophan and $40 \mathrm{mg} / \mathrm{L}$ leucine.

\section{General DNA manipulations}

General DNA manipulations in E. coli or S. cerevisiae were performed according to standard methods [64, 
65]. Polymerase chain reaction (PCR) was conducted using high-fidelity DNA polymerase KOD plus according to the manufacturer's instruction (TOYOBO, Japan). The oligonucleotide primers used in this study are listed in Additional file 1: Table S3. Purification of DNA fragments was performed using PCR Clean-up kit or DNA Gel Extraction kit (Axygen scientific Inc., USA). Total RNA was isolated from yeast cells by using the hot phenol method [65]. Gene transcription was analyzed by quantitative real-time PCR (qRT-PCR) using the Quant one-step qRT-PCR kit (SYBR Green) and LightCycler 96 System (Roche, Switzerland). Data were processed by the second-derivative maximum method of LightCycler 96 software SW1.1 with housekeeping gene $A C T 1$ as a control to calculate the relative transcription level of each target gene.

\section{Construction of recombinant yeast strains}

The plasmids used in this study are listed in Additional file 1: Table S2. The regulatory element cassette containing the $A D H 1$ promoter, $A D H 1$ terminator and the multiple cloning sites (MCS) was amplified from plasmid pAUR123 (TaKaRa) by PCR with primer pair ADH1-F/ ADH1-R. The amplified 990-bp DNA fragment was digested with HindIII/EcoRI, and then inserted into the corresponding sites of plasmid YEp352 [66] to generate plasmid pYEA1. For overexpression of $H Y P 2$, the 474 bp coding region of HYP2 (Accession number NM_001178849.3) was amplified from S. cerevisiae YS58 genomic DNA with primer pair HYP2-F1/HYP2-R1. After digested by KpnI/SacI, HYP2 was inserted into the corresponding sites of pYEA1 to generate plasmid pYEAH. Two DNA fragments $\mathrm{P}_{\mathrm{ADH1}}{ }^{-1}$ and $\mathrm{P}_{\mathrm{ADH1}}{ }^{-2}$ corresponding to the $A D H 1$ promoter region (Accession number KY704468) were amplified from genomic DNA of $S$. cerevisiae YS58 using primer pairs ADH1-DF/ ADH1-DR and ADH1-DF/ADH1-LR, respectively, and then inserted into the EcoRI/BamHI sites or EcoRI/KpnI sites of plasmid YEp352 to generate plasmid pYEA2 and PYEA3. DNA fragment covering the coding region and terminator of DYS1 (Accession number BK006934, 1449 bp) or LIA1 (Accession number BK006943, $1327 \mathrm{bp}$ ) was amplified from genomic DNA of yeast YS58 by primer pair DYS1-F1/DYS-R1 or LIA1-F1/LIA1-R1, and inserted into plasmid pYEA2 or pYEA3 after digested by BamHI/HindIII or KpnI/HindIII, respectively, to generate recombinant plasmid pYEAD or pYEAL. All PCR products were verified by DNA sequencing, and all the plasmids were confirmed by restriction analysis.

Plasmids pYEAH, pYEAD and PYEAL were introduced into $S$. cerevisiae YS58 to generate recombinant strains YS58-HYP2, YS58-DYS1 and YS58-LIA1, respectively. As a control, S. cerevisiae YS58 was transformed with empty vector pYEA1 to generate control strain YS58-V. All transformants were screened on SC-Ura plates using URA3 as the selectable marker and confirmed by PCR analysis. The genetic stability of yeast strains was analyzed as described previously [51].

To compare abundance of target proteins in yeast cells, GFP-tagged strategy was exploited. The $0.9 \mathrm{~kb}$ DNA fragment containing coding region of $g f p 5$ and $A D H 1$ terminator was amplified from plasmid pYCAGA using primers GFP-F and GFP-R, while $1.4 \mathrm{~kb}$ geneticin (G418) resistant gene KanMX4 was amplified from plasmid pFA6a-KanMX4 [67] using primers KanMX-F and KanMX-R. The $g f p-K a n M X$ cassette was obtained by overlap PCR with primer pair GFP-F/KanMX-R. For expression of GFP-tagged proteins, three primer pairs $(\mathrm{X}-1 / \mathrm{X}-2, \mathrm{X}-3 / \mathrm{X}-4$ and $\mathrm{X}-5 / \mathrm{X}-6)$ were synthesized for each target gene. As indicated in Fig. 4a, primer pairs $\mathrm{X}-1 / \mathrm{X}-2, \mathrm{X}-3 / \mathrm{X}-4$ and $\mathrm{X}-5 / \mathrm{X}-6$ were used to amplify the 3 -terminal coding sequence of target gene $(\mathrm{X})$, the $g f p-K a n M X$ cassette and the terminator region of target gene (Xtt), respectively. Then a recombinant DNA fragment $X$-gfp-KanMX-Xtt was obtained by overlap PCR with primer pair X1/X6. S. cerevisiae YS58 was transformed with each DNA fragment $X$-gfp-KanMX-Xtt to generate a series of recombinant yeast strains, designated as YS58-XG, respectively, in which the native locus of target gene on chromosome was replaced by $g f p$-fused target gene by double cross-over recombination to produce GFP-tagged target protein.

For overexpression of $U M E 6$, DNA fragment covering 2511-bp coding region of UME6 (Accession number NM_001180515.1) was amplified from genome of YS58 by PCR using primers UME6-ORF-F and UME6ORF-R. After digested by SalI/XbaI, the coding region of UME6 was inserted into the corresponding sites of pYEA1 to generate plasmid pYEAU6, which then was transformed into S. cerevisiae YS58 to generate recombinant strain YS58-UME6. For deletion of UME6, a DNA fragment covering URA3 flanked, respectively, by $5^{\prime}$-sequence and $3^{\prime}$-sequence of UME6 (Accession number NC_001136.10) was obtained from plasmid pYEA1 by PCR using primers UME6-URA3-F and UME6-URA3-R, and then was transformed into $S$. cerevisiae YS58 to construct UME6 knockout strain YS58ume6 using $U R A 3$ as the selective marker. Moreover, a DNA fragment covering LEU2 flanked, respectively, by $5^{\prime}$-sequence and $3^{\prime}$-sequence of UME6 was obtained from genome of YS58 by PCR using primers UME6LEU2-F and UME6-LEU2-R, and then was used to generate UME6 knockout strain YS58-HYP2-ume6 using $L E U 2$ as the selective marker. 


\section{Stress tolerance assay}

Tolerance of yeast cells to different stresses were compared by both spot dilution assay on solid media and growth profiles in liquid cultures [68]. Yeast cells were precultured in $2 \mathrm{~mL}$ of $\mathrm{SC}$-Ura at $30^{\circ} \mathrm{C}$ for $18 \mathrm{~h}$ (the midexponential phase), and then harvested by centrifugation at $5000 \times g$ for $5 \mathrm{~min}$, washed twice with sterile water and resuspended in sterile water to a final cell concentration equivalent to 0.1 of $O D_{600}$. After diluted serially, $5 \mu \mathrm{L}$ of each tenfold dilution $\left(10^{-1}-10^{-3}\right)$ was spotted onto SCUra agar plates and agar plates containing different concentrations of acetic acid, ethanol or furfural, and then incubated at $30{ }^{\circ} \mathrm{C}$ for $48 \mathrm{~h}$. For analysis of acetic acid tolerance, the $\mathrm{pH}$ of media was adjusted to 4.2 with $2 \mathrm{M}$ $\mathrm{HCl}$. For analysis of thermotolerance, yeast cells were incubated at different temperatures.

Acetic acid tolerance was also analyzed by liquid growth assay. Yeast cells precultured in SC-Ura medium at $30^{\circ} \mathrm{C}$ for $18 \mathrm{~h}$ were inoculated into $50 \mathrm{~mL} \mathrm{SC-Ura}$ medium containing $87 \mathrm{mM}$ or $105 \mathrm{mM}$ acetic acid, respectively, to a final cell density equivalent to about 0.05 of absorbance at $600 \mathrm{~nm}\left(O D_{600}\right)$. Cultivation was performed at $30^{\circ} \mathrm{C}$ with an agitation of $200 \mathrm{rpm}$, and the cell growth was monitored periodically. Three fundamental growth variables, growth lag (the intercept of the initial density and the slope), growth rate (the slope of the exponential phase of the growth curve) and growth efficiency (the total change in density for cells reached stationary phase) [49], were used to characterize the cell growth of different yeast strains under acetic acid stress.

For cell viability assay, yeast cells grown to the midexponential phase were harvested and resuspended in $5 \mathrm{~mL}$ of $210 \mathrm{mM}$ acetic acid solution with adjusted $\mathrm{pH}$ of 4.2 , in which the final cell concentration was controlled to 0.8 of $O D_{600}$. As controls, same yeast cells were also resuspended in $5 \mathrm{~mL}$ of sterile water. Cell suspension was incubated at $30^{\circ} \mathrm{C}$ with an agitation of $200 \mathrm{rpm} .100 \mu \mathrm{L}$ of sample was drawn at different time and diluted serially. The serial dilutions were properly spread onto YPD plates. After $48 \mathrm{~h}$ of incubation at $30^{\circ} \mathrm{C}$, colony-forming units (CFU) were counted. Survival rate of yeast cells was calculated as the percentage of $\mathrm{CFU}$ at the specific time point and the CFU at starting time.

\section{Measurement of fluorescence intensity of GFP in yeast cells} For determination of the GFP fluorescence intensity, yeast cells were precultured in SC-Ura for $18 \mathrm{~h}$ at $30^{\circ} \mathrm{C}$ with shaking, and then resuspended in $5 \mathrm{~mL}$ fresh SCUra supplied with or without $87 \mathrm{mM}$ acetic acid $(\mathrm{pH}$ 4.2) to a final cell density equivalent to an $O D_{600}$ of 0.8 . Cultivation was performed at $30^{\circ} \mathrm{C}$ with an agitation of $200 \mathrm{rpm}$. Yeast cells were harvested after $4 \mathrm{~h}$ and $8 \mathrm{~h}$, respectively, washed twice with sterile water and resuspended in the same volume of sterile water. The fluorescence intensity (FI) of yeast cells was detected using a Synergy H4 hybrid reader (BioTek, USA) with excitation at $488 \mathrm{~nm}$ and emission at $509 \mathrm{~nm}$. Meantime, $O D_{600}$ was measured. Relative fluorescence unit (RFU), the rate of FI and $O D_{600}$, was applied to characterize the abundance of GFP-tagged proteins. Translation efficiency was defined as the ratio of protein level to the corresponding mRNA level of a particular gene.

\section{Statistical analysis}

All experiments were performed in three independent biological replicates, and at least three independent experiments were done on separate occasions. All data were analyzed statistically using Data Analysis and Graphing Software (OriginPro 7.5, OriginLab Corporation). Data are presented as the means of the results of three independent experiments and the standard deviations.

\section{Supplementary Information}

The online version contains supplementary material available at https://doi. org/10.1186/s13068-021-01885-2.

\begin{abstract}
Additional file 1: Table S1. Functional categories of polyproline proteins possibly involved in acetic acid response in S. cerevisiae. Table S2. Strains and plasmids used in this study. Table S3. Primers used in this study. Figure $\mathbf{S 1}$. Cell growth and glucose utilization of different yeast strains. Yeast cells precultured in SC-Ura medium at $30^{\circ} \mathrm{C}$ with an agitation of $200 \mathrm{rpm}$ for $20 \mathrm{~h}$ were inoculated into $100 \mathrm{~mL}$ synthetic complete fermentation medium (SCFM) containing $100 \mathrm{~g} / \mathrm{L}$ glucose, $6.7 \mathrm{~g} / \mathrm{L}$ yeast nitrogen base without amino acids, $5 \mathrm{~g} / \mathrm{L}$ urea, $40 \mathrm{mg} / \mathrm{L}$ histidine, $40 \mathrm{mg} / \mathrm{L}$ tryptophan and $40 \mathrm{mg} / \mathrm{L}$ leucine to a final cell density equivalent to about 2.0 of absorbance at $600 \mathrm{~nm}\left(O D_{600}\right)$. Cultivation was performed in the absence (YS58-V and YS-58-HYP2) or presence of $87 \mathrm{mM}$ acetic acid (pH 4.2) (YS58$V(A A)$ and YS-58-HYP2 (AA)) at $30{ }^{\circ} \mathrm{C}$ with an agitation of $60 \mathrm{rpm}$. Samples were withdrawn periodically for analyses of cell growth and residual glucose. The level of residual glucose was detected using the dinitrosalicylic acid method. Data are presented as the means of the results of three independent experiments. Error bars represent standard deviations. Figure S2. Effect of Ume6p activity and elF5A activity on transcription of BEM4, BUD21 and IME4. Yeast cells were cultured under conditions with or without $87 \mathrm{mM}$ acetic acid ( $\mathrm{pH}$ 4.2) for $4 \mathrm{~h}$. Total RNA was isolated from yeast cells by using the hot phenol method. Gene transcription was analyzed by quantitative real-time PCR (qRT-PCR) using the Quant one-step qRT-PCR kit (SYBR Green) and LightCycler 96 System (Roche, Switzerland). Data were processed by the second-derivative maximum method of LightCycler 96 software SW1.1 with housekeeping gene ACT1 as a control to calculate the relative transcription level of each target gene. The relative transcription of target gene in YS58-V under non-stressed condition was defined as a value of 1, respectively. Data are presented as the means of the results of three independent experiments. Error bars represent standard deviations.
\end{abstract}

\section{Abbreviations}

DHS: Deoxyhypusine synthase; DOHH: Deoxyhypusine hydroxylase; LB medium: Luria-Bertani medium containing (per liter) $5 \mathrm{~g}$ yeast extract, $10 \mathrm{~g}$ tryptone and $10 \mathrm{~g} \mathrm{NaCl}$; YPD medium: Yeast extract peptone dextrose medium containing (per liter) $10 \mathrm{~g}$ yeast extract, $20 \mathrm{~g}$ peptone and $20 \mathrm{~g}$ glucose; SC medium: Synthetic complete medium containing (per liter) $6.7 \mathrm{~g}$ 
yeast nitrogen base without amino acids, $10 \mathrm{~g}$ glucose, $40 \mathrm{mg}$ histidine, $40 \mathrm{mg}$ tryptophan, $40 \mathrm{mg}$ leucine and $30 \mathrm{mg}$ uracil; SC-Ura: SC medium without uracil; AA: Acetic acid; PCR: Polymerase chain reaction; qRT-PCR: Quantitative real-time PCR; MCS: Multiple cloning sites; GFP: Green fluorescent protein; $\mathrm{OD}_{600}$ : Optical density at $600 \mathrm{~nm}$; CFU: Colony-forming units; Fl: Fluorescence intensity; RFU: Relative fluorescence unit, the rate of $\mathrm{FI}$ and $\mathrm{OD}_{600} ; \mathrm{SGD}$ : Saccharomyces Genome Database; GO: Gene ontology; URS1: Upstream repressor site 1.

\section{Acknowledgements \\ Not applicable.}

\section{Authors' contributions}

$X H$ and $Y C$ designed and supervised the study. $H Z, Y C, X G$ and $C Z$ performed the experiments and data analyses. ZD and ZW performed all the bioinformatics analyses. $\mathrm{XH}, \mathrm{YC}$ and $\mathrm{HZ}$ wrote and revised the manuscript. All authors read and approved the final manuscript.

\section{Funding}

This work was supported by the National Key R\&D Program of China (No. 2018YFD0500605) and National Natural Science Foundation of China (31200073).

\section{Availability of data and materials}

The datasets supporting the conclusions of this article are included within the article and its additional file.

\section{Ethics approval and consent to participate}

Not applicable.

\section{Consent for publication}

All authors read and approved the final manuscript.

\section{Competing interests}

The authors declare that they have no competing interests.

\section{Author details}

${ }^{1}$ CAS Key Laboratory of Microbial Physiological and Metabolic Engineering, State Key Laboratory of Mycology, Institute of Microbiology, Chinese Academy of Sciences, Beijing 100101, China. ${ }^{2}$ College of Life Sciences, University of Chinese Academy of Sciences, Beijing 100049, China.

Received: 30 October 2020 Accepted: 16 January 2021

Published online: 08 February 2021

\section{References}

1. Kemper WM, Berry KW, Merrick WC. Purification and properties of rabbit reticulocyte protein synthesis initiation factors $\mathrm{M} 2 \mathrm{Ba}$ and $\mathrm{M} 2 \mathrm{~B} \beta$. J Biol Chem. 1976;251:5551-7.

2. Schreier MH, Erni B, Staehelin T. Initiation of mammalian protein synthesis: purification and characterization of seven initiation factors. J Mol Biol. 1977;116:727-53.

3. Benne R, Hershey JW. The mechanism of action of protein synthesis initiation factors from rabbit reticulocytes. J Biol Chem. 1978;253:3078-87.

4. Park MHCH, Folk JE. Identification of hypusine, an unusual amino acid, in a protein from human lymphocytes and of spermidine as its biosynthetic precursor. Proc Natl Acad Sci USA. 1981;78:2869-73.

5. Park MH, Cooper HL, Folk JE. The biosynthesis of protein-bound hypusine ( $\mathrm{N}^{\epsilon}$-(4-amino-2-hydroxybutyl)-lysine): lysine as the amino acid precursor and the intermediate role of deoxyhypusine ( $\mathrm{N}^{\epsilon}$-(4-aminobutyl)lysine). J Biol Chem. 1982;257:7217-22.

6. Park MH. The post-translational synthesis of a polyamine-derived amino acid, hypusine, in the eukaryotic translation initiation factor 5A (elF5A). J Biochem. 2006;139:161-9.

7. Park MH, Wolff EC, Folk JE. Hypusine: its post-translational formation in eukaryotic initiation factor $5 \mathrm{a}$ and its potential role in cellular regulation. BioFactors. 1993;4:95-104.

8. Park MH, Lee YB, Joe YA. Hypusine is essential for eukaryotic cell proliferation. Biol Signals. 1997;6:115-23.
9. Bartig D, Klink SHF. The unique posttranslational modification leading to deoxyhypusine or hypusine is a general feature of the Archebacterial kingdom. Syst Appl Microbiol. 1990;13:112-6.

10. Park MH, Nishimura K, Zanelli CF, Valentini SR. Functional significance of elF5A and its hypusine modification in eukaryotes. Amino Acids. 2010;38:491-500.

11. Schnier J, Schwelberger HG, Smit-McBride Z, Kang HA, Hershey JWB. Translation initiation factor $5 \mathrm{~A}$ and its hypusine modification are essential for cell viability in the yeast Saccharomyces cerevisiae. Mol Cell Biol. 1991;11:3105-14.

12. Sasaki K, Abid MR, Miyazaki M. Deoxyhypusine synthase gene is essential for cell viability in the yeast Saccharomyces cerevisiae. FEBS Lett. 1996;384:151-4.

13. Chawla B, Jhingran A, Singh S, Tyagi N, Park MH, Srinivasan N, Roberts SC, Madhubala R. Identification and characterization of a novel deoxyhypusine synthase in Leishmania donovani. J Biol Chem. 2010;285:453-63.

14. Henderson A, Hershey JW. Eukaryotic translation initiation factor (eIF) $5 \mathrm{~A}$ stimulates protein synthesis in Saccharomyces cerevisiae. Proc Natl Acad Sci USA. 2011;108:6415-9.

15. Zanelli CF, Maragno AL, Gregio AP, Komili S, Pandolfi JR, Mestriner CA, Lustri WR, Valentini SR. elF5A binds to translational machinery components and affects translation in yeast. Biochem Biophys Res Commun. 2006;348(4):1358-66.

16. Gregio AP, Cano VP, Avaca JS, Valentini SR, Zanelli CF. elF5A has a function in the elongation step of translation in yeast. Biochem Biophys Res Commun. 2009;380:785-90.

17. Saini P, Eyler DE, Green R, Dever TE. Hypusine-containing protein elF5A promotes translation elongation. Nature. 2009;459:118-21.

18. Dias CA, Gregio AP, Rossi D, Galva־o FC, Watanabe TF, Park MH, Valentini $\mathrm{SR}$, Zanelli CF. elF5A interacts functionally with eEF2. Amino Acids. 2012:42(2-3):697-702.

19. Kang HA, Hershey JW. Effect of initiation factor elF-5A depletion on protein synthesis and proliferation of Saccharomyces cerevisiae. J Biol Chem. 1994;269:3934-40.

20. Gutierrez E, Shin BS, Woolstenhulme CJ, Kim JR, Saini P, Buskirk AR, Dever TE. elF5A promotes translation of polyproline motifs. Mol Cell. 2013;51:35-45.

21. Williamson MP. The structure and function of proline-rich regions in proteins. Biochem J. 1994;297:249-60.

22. Kay BK, Williamson MP, Sudol M. The importance of being proline: the interaction of proline-rich motifs in signaling proteins with their cognate domains. FASEB J. 2000;14:231-41.

23. Mandal A, Mandal S, Park MH. Genome-wide analyses and functional classification of proline repeat-rich proteins: potential role of elF5A in eukaryotic evolution. PLoS ONE. 2014;9:e111800.

24. Gibson BR, Lawrence SJ, Leclaire JP, Powell CD, Smart KA. Yeast responses to stresses associated with industrial brewery handling. FEMS Microbiol Rev. 2007;31:535-69.

25. Palmqvist $E$, Hahn-Hägerdal B. Fermentation of lignocellulosic hydrolysates. II: inhibitors and mechanisms of inhibition. Bioresour Technol. 2000;74:25-33.

26. Kavšček M, Stražar M, Curk T, Natter K, Petrovič U. Yeast as a cell factory: current state and perspectives. Microb Cell Fact. 2015;14:94.

27. Graves T, Narendranath N, Dawson K, Power R. Effect of pH and lactic or acetic acid on ethanol productivity by Saccharomyces cerevisiae in corn mash. J Ind Microbiol Biotechnol. 2006;33:469-74.

28. Mira NP, Teixeira MC, Sá-Correia I. Adaptation and tolerance to weak acid stress in Saccharomyces cerevisiae: a genome-wide view. OMICS. 2010;14:525-40.

29. Mira NP, Palma M, Guerreiro JF, Sa-Correia I. Genome-wide identification of Saccharomyces cerevisiae genes required for tolerance to acetic acid. Microb Cell Fact. 2010;9:79.

30. Almario MP, Reyes LH, Kao KC. Evolutionary engineering of Saccharomyces cerevisiae for enhanced tolerance to hydrolysates of lignocellulosic biomass. Biotechnol Bioeng. 2013;110:2616-23.

31. Sanchez-i-Nogue V, Narayanan V, Gorwa-Grauslund MF. Short-term adaptation improves the fermentation performance of Saccharomyces cerevisiae in the presence of acetic acid at low pH. Appl Microbiol Biotechnol. 2013;97:7517-25. 
32. Piper P, Calderon CO, Hatzixanthis K, Mollapour M. Weak acid adaptation: the stress response that confers yeasts with resistance to organic acid food preservatives. Microbiology. 2001;147:2635-42.

33. Orij R, Brul S, Smits GJ. Intracellular pH is a tightly controlled signal in yeast. Biochim Biophys Acta. 2011;1810:933-44.

34. Palma M, Guerreiro JF, Sá-Correia I. Adaptive response and tolerance to acetic acid in Saccharomyces cerevisiae and Zygosaccharomyces bailii: A physiological genomics perspective. Front Microbiol. 2018;9:274.

35. Wohl T, Klier H, Ammer H, Lottspeich F, Magdolen V. The HYP2 gene of Saccharomyces cerevisiae is essential for aerobic growth: characterization of different isoforms of the hypusine-containing protein Hyp2p and analysis of gene disruption mutants. Mol Gen Genet. 1993;241:305-11.

36. Park JH, Aravind L, Wolff EC, Kaevel J, Kim YS, Park MH. Molecular cloning, expression, and structural prediction of deoxyhypusine hydroxylase: a HEAT-repeat-containing metalloenzyme. Proc Natl Acad Sci USA. 2006;103:51-6.

37. Dias CA, Cano VS, Rangel SM, Apponi LH, Frigieri MC, Muniz JR, Garcia W, Park MH, Garratt RC, Zanelli CF, Valentini SR. Structural modeling and mutational analysis of yeast eukaryotic translation initiation factor $5 \mathrm{~A}$ reveal new critical residues and reinforce its involvement in protein synthesis. FEBS J. 2008;275:1874-88.

38. Gentz PM, Blatch GL, Dorrington RA. Dimerization of the yeast eukaryotic translation initiation factor $5 \mathrm{~A}$ requires hypusine and is RNA dependent. FEBS J. 2009;276:695-706.

39. Kawahata M, Masaki K, Fujii T, lefuji H. Yeast genes involved in response to lactic acid and acetic acid: acidic conditions caused by the organic acids in Saccharomyces cerevisiae cultures induce expression of intracellular metal metabolism genes regulated by Aft 1p. FEMS Yeast Res. 2006;6:924-36.

40. Sousa M, Duarte AM, Fernandes TR, Chaves SR, Pacheco A, Leão C, CôrteReal M, Sousa MJ. Genome-wide identification of genes involved in the positive and negative regulation of acetic acid-induced programmed cell death in Saccharomyces cerevisiae. BMC Genomics. 2013;14:838.

41. Goldmark JP, Fazzio TG, Estep PW, Church GM, Tsukiyama T. The Isw2 chromatin remodeling complex represses early meiotic genes upon recruitment by Ume6p. Cell. 2000;103:423-33.

42. Williams RM, Primig M, Washburn BK, Winzeler EA, Bellis M, de Menthiere C, Davis RW, Esposito RE. The Ume6 regulon coordinates metabolic and meiotic gene expression in yeast. Proc Natl Acad Sci USA. 2002;99:13431-6.

43. Banerjee M, Uppuluri P, Zhao XR, Carlisle PL, Vipulanandan G, Villar CC, López-Ribot JL, Kadosh D. Expression of UME6, a key regulator of Candida albicans hyphal development, enhances biofilm formation via Hgc1- and Sun41-dependent mechanisms. Eukaryot Cell. 2013;12:224-32.

44. Lardenois A, Becker E, Walther T, Law MJ, Xie B, Demougin P, Strich R, Primig M. Global alterations of the transcriptional landscape during yeast growth and development in the absence of Ume6-dependent chromatin modification. Mol Genet Genomics. 2015;290:2031-46.

45. Pelechano V, Alepuz P. elF5A facilitates translation termination globally and promotes the elongation of many non polyproline-specific tripeptide sequences. Nucleic Acids Res. 2017;45:7326-38.

46. Schuller AP, Wu CC, Dever TE, Buskirk AR, Green R. elF5A Functions globally in translation elongation and termination. Mol Cell. 2017;66:194-205.

47. Shin BS, Katoh T, Gutierrez E, Kim J, Suga H, Dever TE. Amino acid substrates impose polyamine, elF5A, or hypusine requirement for peptide synthesis. Nucleic Acids Res. 2017;45:8392-402.

48. Chatterjee I, Gross SR, Kinzy TG, Chen KY. Rapid depletion of mutant eukaryotic initiation factor $5 \mathrm{~A}$ at restrictive temperature reveals connections to actin cytoskeleton and cell cycle progression. Mol Genet Genom ics. 2006;275:264-76.

49. Li Z, Vizeacoumar FJ, Bahr S, Li J, Warringer J, Vizeacoumar FS, Min R, Vandersluis B, Bellay J, Devit M, Fleming JA, Stephens A, Haase J, Lin ZY, Baryshnikova A, Lu H, Yan Z, Jin K, Barker S, Datti A, Giaever G, Nislow C, Bulawa C, Myers CL, Costanzo M, Gingras AC, Zhang Z, Blomberg A Bloom K, Andrews B, Boone C. Systematic exploration of essential yeast gene function with temperature-sensitive mutants. Nat Biotechnol. 2011;29:361-7.

50. Xu J, Zhang B, Jiang C, Ming F. RcelF5A, encoding an eukaryotic translation initiation factor $5 \mathrm{~A}$ in Rosa chinensis, can enhance thermotolerance, oxidative and osmotic stress resistance of Arabidopsis thaliana. Plant Mol Biol. 2011;75:167-78.

51. Lu Y, Cheng YF, He XP, Guo XN, Zhang BR. Improvement of robustness and ethanol production of ethanologenic Saccharomyces cerevisiae under costress of heat and inhibitors. J Ind Microbiol Biotechnol. 2012;39:73-80.

52. Zheng $D Q$, Wu XC, Wang PM, Chi XQ, Tao XL, Li P, Jiang XH, Zhao YH. Drug resistance marker-aided genome shuffling to improve acetic acid tolerance in Saccharomyces cerevisiae. J Ind Microbiol Biotechnol. 2011:38:415-22.

53. Harbison CT, Gordon DB, Lee TI, Rinaldi NJ, Macisaac KD, Danford TW, Hannett NM, Tagne JB, Reynolds DB, Yoo J, Jennings EG, Zeitlinger J, Pokholok DK, Kellis M, Rolfe PA, Takusagawa KT, Lander ES, Gifford DK, Fraenkel E, Young RA. Transcriptional regulatory code of a eukaryotic genome. Nature. 2004;431:99-104.

54. Lardenois A, Stuparevic I, Liu Y, Law MJ, Becker E, Smagulova F, Waern K, Guilleux MH, Horecka J, Chu A, Kervarrec C, Strich R, Snyder M, Davis RW, Steinmetz LM, Primig M. The conserved histone deacetylase Rpd3 and its DNA binding subunit Ume6 control dynamic transcript architecture during mitotic growth and meiotic development. Nucleic Acids Res. 2015;43:115-28.

55. Mallorya MJ, Lawa MJ, Sternerb DE, Bergerc SL, Stricha R. Gcn5p-dependent acetylation induces degradation of the meiotic transcriptional repressor Ume6p. Mol Biol Cell. 2012;23:1609-17.

56. Law MJ, Mallory MJ, Dunbrack RL Jr, Stricha R. Acetylation of the transcriptional repressor Ume6p allows efficient promoter release and timely induction of the meiotic transient transcription program in yeast. Mol Cell Biol. 2014;34:631-42.

57. Jani NM, Lopes JM. Transcription regulation of the Saccharomyces cerevisiae PIS1 gene by inositol and the pleiotropic regulator, Ume6p. Mol Microbiol. 2008;70:1529-39.

58. Gallagher JE, Dunbar DA, Granneman S, Mitchell BM, Osheim Y, Beyer AL, Baserga SJ. RNA polymerase I transcription and pre-rRNA processing are linked by specific SSU processome components. Genes Dev. 2004;18:2506-17.

59. Mutumwinka D, Zhao SB, Liu YS, Mensah EO, Gao XD, Fujita M. PiggyBacbased screening identified BEM4 as a suppressor to rescue growth defects in och1-disrupted yeast cells. Biosci Biotechnol Biochem. 2018:82:1497-507.

60. Yadav PK, Rajasekharan R. The m6A methyltransferase Ime4 epitranscriptionally regulates triacylglycerol metabolism and vacuolar morphology in haploid yeast cells. J Biol Chem. 2017;292:13727-44.

61. Yadav PK, Rajasekharan R. The $m^{6} \mathrm{~A}$ methyltransferase Ime4 and mitochondrial functions in yeast. Curr Genet. 2018;64:353-7.

62. Bushkin GG, Pincus D, Morgan JT, Richardson K, Lewis C, Chan SH, Bartel DP, Fink GR. $\mathrm{m}^{6} \mathrm{~A}$ modification of a $3^{\prime}$ UTR site reduces RME1 mRNA levels to promote meiosis. Nat Commun. 2019;10:3414.

63. Teunissen ARH, Holub E, Hucht JVD. Physical localization of the flocculation gene FLO1 on chromosome I of Saccharomyces cerevisiae. Yeast. 1993:9:1-10.

64. Sambrook J, Russell D. Molecular cloning: A laboratory manual. Cold Spring Harbor, New York: Cold Spring Harbor Laboratory Press; 2001.

65. Adams A, Gottschling DE, Kaiser CA, Stearns T. Methods in yeast genetics: A cold spring harbor laboratory course manual. Cold Spring Harbor, New York: Cold Spring Harbor Laboratory Press; 1997.

66. Hill JE, Myers AM, Koerner TJ, Tzagoloff A. Yeast/E. coli shuttle vectors with multiple unique restriction sites. Yeast. 1986;2:163-7.

67. Wach A, Brachat A, Pohlmann R, Philippsen P. New heterologous modules for classical or PCR-based gene disruptions in Saccharomyces cerevisiae. Yeast. 1994;10:1793-808.

68. Chen Y, Du Z, Zhu H, Guo X, He X. Protective effects of arginine on Saccharomyces cerevisiae against ethanol stress. Sci Rep. 2016;6:31311.

\section{Publisher's Note}

Springer Nature remains neutral with regard to jurisdictional claims in published maps and institutional affiliations. 